\title{
Cigarette Smoking Following a Prolonged Mental Task Exaggerates Vasoconstriction in Glabrous Skin in Habitual Smokers
}

\author{
Kouhei UeHARA ${ }^{1}$, Ryoko SONE ${ }^{1}$ and Fumio YAMAZAKI ${ }^{2 *}$ \\ ${ }^{1}$ Department of Exercise and Health Science, Faculty of Education, University of Yamaguchi 753-8513, \\ Japan \\ ${ }^{2}$ Division of Human, Information and Life Sciences, School of Health Sciences, University of \\ Occupational and Environmental Health, Japan. Yahatanishi-ku, Kitakyushu 807-8555, Japan
}

\begin{abstract}
In the present study, to test the hypothesis that cigarette smoking and physical exercise induce different influences on peripheral vasomotor control after mental stress, we examined the physiological responses, including skin vasomotor responses, to smoking and exercise in six healthy smokers. The smokers performed $2 \mathrm{hr}$ of mental arithmetic tasks (MT) followed by smoking or bicycle exercise $(108 \pm 7 \mathrm{~W})$ for $10 \mathrm{~min}$ or a time control (i.e. rest without smoking) under thermally comfortable conditions $\left(25^{\circ} \mathrm{C}\right)$. Skin blood flow (laser-Doppler flowmetry) was monitored at glabrous (palm) and nonglabrous (forearm, forehead) sites. Cutaneous vascular conductance (CVC) was evaluated from the ratio of blood flow to mean arterial pressure (MAP). The prolonged MT increased MAP from $77.7 \pm 2.7 \mathrm{mmHg}$ to $86.0 \pm 3.0 \mathrm{mmHg}$ and reduced CVC in the palm by $27.4 \pm 5.6 \%$, but did not change those in the forearm and forehead. Smoking after MT further decreased CVC in the palm, and the smokinginduced reduction in CVC persisted until 20 min after smoking. Meanwhile, $\mathrm{CVC}$ in the forearm and forehead transiently and minimally decreased during smoking. Exercise after MT increased CVC at the three sites, and the exerciseinduced elevation of CVC in the palm persisted until $30 \mathrm{~min}$ after exercise. In the time control experiments, each variable remained unchanged throughout the recovery period of MT. It was suggested that smoking causes additional vasoconstriction in glabrous skin after prolonged MT, while the exercise-associated vasodilator effect counteracts the vasoconstrictor action of MT. We speculate that long-term mental stress and smoking behavior may synergistically develop chronic stress-induced vascular dysfunction, and the stress-related disorders may be reduced by habitual enforcement of moderate exercise.
\end{abstract}

Key words : skin blood flow, mental stress, exercise, smoking, sweating.

(Received 17 May 2010, accepted 17 August 2010)

\footnotetext{
*Corresponding author: Fumio Yamazaki, Division of Human, Information and Life Sciences, School of Health Sciences, Univ. of Occupational and Environmental Health (UOEH), Japan. Yahatanishi-ku, Kitakyushu, Fukuoka 807-8555, Japan, E-mail: yamazaki@health.uoeh-u.ac.jp
} 


\section{Introduction}

Mental stress experienced at work influences vasomotor control in various organs via the sympathetic nervous system [1-3]. Acute mental stress induces blood pressure elevation and triggers myocardial ischemia and endothelial dysfunction [4-6], while chronic exposure to mental stress induces cardiovascular diseases, including hypertension and peripheral vascular disorders [7]. In most previous studies $[1,3,6,8-13]$, short-term (2-10 min) mental tasks (MT) have been used to determine the cardiovascular responses to mental stress. These studies showed that shortterm MT causes vasoconstriction in muscle, viscera and skin, and that stress-induced vasoconstrictor responses rapidly disappeared after terminating the stimuli. By contrast, Nielsen et al. [14] recently found a lack of recovery of blood pressure and the finger skin blood flow (SkBF) response to $1 \mathrm{hr}$ mental stress. A slow vascular recovery after prolonged MT in healthy subjects may be a risk for developing chronic stress-related disorders later in life [14]. It is important to note that cutaneous circulation has emerged as a potentially representative vascular bed to examine the mechanisms of microcirculatory function and dysfunction [15].

Cigarette smoking and physical exercise such as body muscle stretching and walking are done during breaks at the work place, although cigarette smoking is mostly prohibited in public spaces in Japan and most smokers use designated smoking areas. Smoking induces vasoconstriction in the coronary artery and skin [16-18], and may exacerbate vasoconstrictor and pressor responses due to mental stress. In contrast, physical exercise elevates body temperature, and the elevated temperature dilates skin vessels to increase heat dissipation. The vasodilator effect of exercise in the skin may counteract mental stress-induced vasoconstriction. However, influences of smoking and exercise on skin vasomotor control after MT are still unknown.

Skin vascular responses to mental stress are greater in glabrous regions such as the palms and soles than in nonglabrous regions such as the forearm and calf $[12,13]$. In addition, skin vascular responses to physical exercise or smoking are not always similar between glabrous regions and nonglabrous regions $[12,17,19-22]$. In the present study, therefore, we examined the effects of smoking and physical exercise on vasomotor control in glabrous and nonglabrous skin after a prolonged MT. We hypothesized that smoking and exercise after MT induce different vascular responses in the skin, and that the different responses are more evident in glabrous regions than in nonglabrous regions.

\section{Methods}

\section{Subjects}

Six male volunteers participated in the experiments. Their average age was $23 \pm 1$ (SE) yr, average weight was $64 \pm 3 \mathrm{~kg}$, and average height was $169 \pm 2 \mathrm{~cm}$. All subjects were healthy smokers who had smoked 11-20 cigarettes per day for $4.3 \pm 1.0$ years with no history of cardiovascular disease. This study was conducted in accordance with the recommendations outlined in the Declaration of Helsinki, and written informed consent was obtained after a thorough explanation of the present study, including its purpose and risks. 


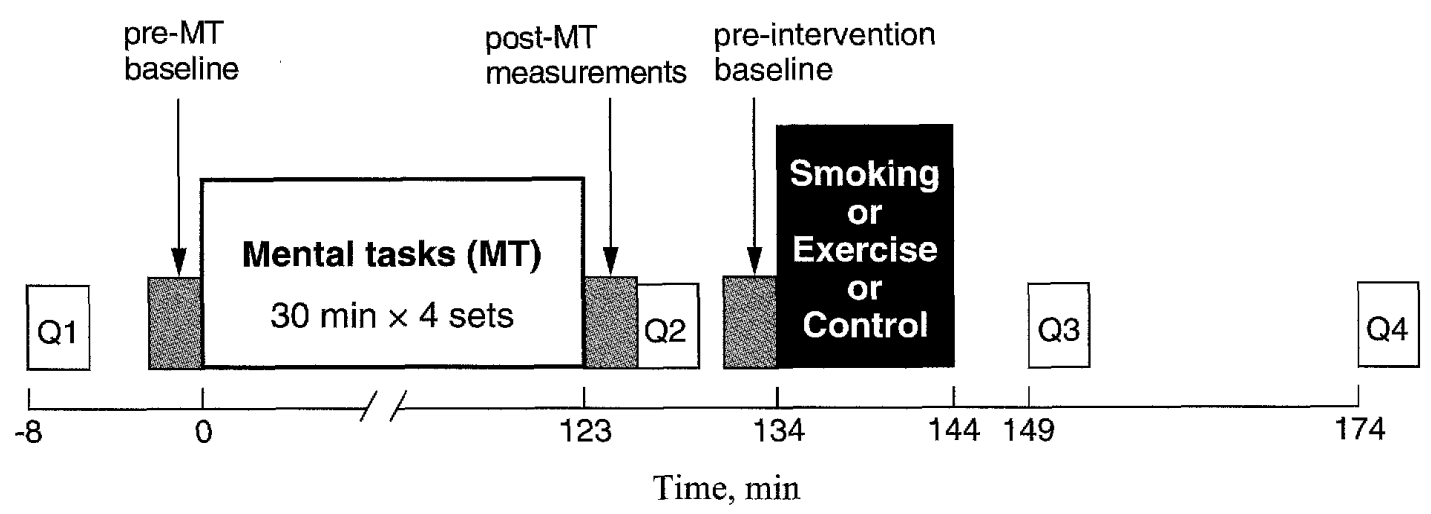

Fig. 1. Experimental protocols. Smoking, cycle exercise or rest without smoking were done for 10 min following 4 sets of 30 min mental tasks (MT) with 1 min breaks between the sets. Q1-Q4, Questionnaires about subjective fatigue were performed four times throughout the experiment.

\section{Measurements}

SkBF was monitored continuously with laser-Doppler flow meters (ALF21, Advance, Tokyo, Japan). Local sweating rates (SR) were measured by the ventilated capsule method. Flow probes located at the center of sweat capsules were applied to the forehead, left forearm and left palm. Dry air was supplied to the sweat capsules $\left(0.64 \mathrm{~cm}^{2}\right.$ area $)$ at a rate of $0.21 \mathrm{~min}^{-1}$. The humidity of the air flowing out of the capsules was measured with capacitance hygrometers (HMP 133Y, Vaisala, Helsinki, Finland). As an index of core temperature, esophageal temperature (Tes) was measured with a polyethylene-sealed thermocouple swallowed via the mouth to $36^{-42} \mathrm{~cm}$ down the esophagus. The Tes probe was located at the highest temperature. Heart rate (HR) was determined by an electrocardiogram (CMs lead) using a telemetric device (Bioview 1000, NEC, Tokyo, Japan). Mean arterial pressure (MAP) was measured continuously by arterial tonometry (JENTOW-7700, Colin, Komaki, Japan) on the left radial artery. Subjective fatigue was evaluated using the Profile of Mood States (POMS) [23].

\section{Experimental procedures and protocols}

The experiments consisted of three different conditions (smoking, exercise, control) following identical MT (Fig. 1). Each experiment was performed at the same hour on separate days, and the order of the three experiments was randomized. The subjects arrived in the laboratory after having abstained from caffeine and alcohol for at least 1 day and from food and smoking for at least 2 and $8 \mathrm{hr}$, respectively. All experiments were conducted in a room with an ambient temperature of $25 \pm 1{ }^{\circ} \mathrm{C}$ and a humidity of $50 \pm 5 \%$. After entering the room, each subject, wearing shorts and a short-sleeved undershirt, rested in the recumbent position on a cycle ergometer (Angio WLP-300, Lode, Holland) for $\sim 40 \mathrm{~min}$. During this period, a cuff for measuring arterial pressure, a thermocouple, sensor probes, and sweat capsules were applied. After a questionnaire about feeling tired and baseline measurements of physiological variables were administered for 3 
min in the pre-MT condition, a prolonged MT which consisted of 4 sets of 30 min mental arithmetic aloud ( $1 \mathrm{~min}$ breaks between the sets) was performed. For the mental arithmetic, the calculations consisting of adding one-digit integers which were indicated on a computer display at a rate of 44 per min, and the subjects answered using a keyboard. After measurements of physiological variables and the questionnaire about feeling tired were done in the post-MT condition, the subjects smoked, exercised or did a time control (i.e. rested with no smoking and no exercise) for 10 min, followed by physiological measurements at rest for $30 \mathrm{~min}$. The subjects were asked about feeling tired at 5 and $30 \mathrm{~min}$ after those interventions. For the smoking intervention, the subjects were asked to smoke 3 standard cigarettes containing $10 \mathrm{mg}$ tar and $0.8 \mathrm{mg}$ nicotine. No attempt was made to impose any strict protocol concerning the frequency or depth of inhalation. To ventilate the cigarette smoke, a transparent vinyl hood $(0.9 \mathrm{~m} \times 0.9 \mathrm{~m}$ wide $\times 1.6 \mathrm{~m}$ height $)$ connected to a ventilation duct was located around each subject for 15 min from 2 min before until 3 min after smoking. For the exercise intervention, the subjects performed cycle exercise at intensity of about $40 \%$ of the HR reserve (target $\mathrm{HR}=125$ beats $/ \mathrm{min}, 108 \pm 7 \mathrm{~W}$ ). The work load was decided using a submaximal exercise test on the day prior to the experiment. In the time control study, the subjects rested in the recumbent position on a cycle ergometer throughout the post-MT period.

\section{Data acquisition and analysis}

The measured variables were recorded by a data acquisition system (Power Lab/16sp, ADInstruments, Colorado Springs, CO, USA) every $1 \mathrm{~s}$ and averaged every $5 \mathrm{~min}$. Cutaneous vascular conductance (CVC) was calculated from the ratio of SkBF to MAP. Changes in CVC were expressed as percent changes from the pre-MT baseline values.

The effects of experimental interventions and time changes in each variable were evaluated using two-way repeated measures ANOVA, followed by Contrasts when a significant difference was detected. In three intervention studies, the values were averaged among the three conditions, since physiological and psychological variables were similarly changed during MT. The effects of MT on the changes in each variable were evaluated using one-way ANOVA followed by Fisher's PLSD tests. Statistical significance was set at $P<0.05$. Data are presented as means $\pm \mathrm{SE}$.

\section{Results}

MT for two hours reduced CVC $(P<0.01)$ in the palm, but not in the forearm or forehead (Table 1). Also, the MT increased SR $(P<0.01)$ in the palm, but not in the forearm or forehead. The MT increased blood pressure $(P<0.01)$ without changing HR or Tes. Subjective fatigue was significantly increased by the MT (Pre-MT, 7.2 \pm 1.4 ; Post-MT, $13.8 \pm 1.7, P<0.01$ ).

Figure 2 shows the CVC responses to smoking, exercise and control interventions after MT. CVC in the palm was reduced $(P<0.05)$ with smoking, and a significant decrease continued until 20 min after smoking. Exercise transiently reduced CVC $(P<0.05)$ in the palm in the early phase, and subsequently increased it $(P<0.05)$ up to $30 \mathrm{~min}$ of the recovery period. Smoking 
Table 1. Changes in physiological variables in a $2 \mathrm{hr}$ mental task

\begin{tabular}{lcc}
\hline \multicolumn{1}{c}{ Variables } & Pre-mental task & Post-mental task \\
\hline CVC in palm, \% & $100 \pm 0$ & $72.6 \pm 5.6^{*}$ \\
CVC in forearm, \% & $100 \pm 0$ & $97.5 \pm 6.9$ \\
CVC in forehead, \% & $100 \pm 0$ & $99.9 \pm 6.0$ \\
SR in palm, $\mathrm{mg} / \mathrm{cm}^{2} / \mathrm{min}$ & $0.06 \pm 0.01$ & $0.16 \pm 0.05^{*}$ \\
SR in forearm, $\mathrm{mg} / \mathrm{cm}^{2} / \mathrm{min}$ & $0.06 \pm 0.01$ & $0.06 \pm 0.01$ \\
$\mathrm{SR}$ in forehead, $\mathrm{mg} / \mathrm{cm}^{2} / \mathrm{min}$ & $0.07 \pm 0.01$ & $0.12 \pm 0.03$ \\
$\mathrm{HR}$, beats $/ \mathrm{min}$ & $60.5 \pm 1.7$ & $60.0 \pm 2.6$ \\
$\mathrm{MAP}, \mathrm{mmHg}$ & $77.7 \pm 2.7$ & $86.0 \pm 3.0^{*}$ \\
Tes, ${ }^{\circ} \mathrm{C}$ & $36.8 \pm 0.0$ & $36.7 \pm 0.1$ \\
\hline
\end{tabular}

CVC: cutaneous vascular conductance, SR: sweat rate, HR: heart rate, MAP: mean arterial pressure, Tes: esophageal temperature, ${ }^{*}: P<0.05$ from pre-mental task

slightly reduced CVC $(P<0.05)$ in the forearm in the early phase, but did not change it in the forehead. Exercise increased CVC $(P<0.05)$ in the forearm and forehead. In the time control experiments, $\mathrm{CVC}$ at each site remained unchanged throughout the post-MT periods.

Figure 3 shows the SR responses to smoking, exercise and control interventions after MT. Smoking slightly, but significantly, increased SR $(P<0.05)$ in the palm, but did not change it in the forearm or forehead. Exercise increased SR $(P<0.05)$ in the three sites. In the time control experiments, SR in each site remained unchanged throughout the post-MT periods.

As shown in Fig. 4, smoking and exercise significantly increased MAP, HR and Tes. The increased feeling of fatigue due to the MT fell to the pre-MT levels at $5 \mathrm{~min}$ after the exercise and control interventions, but remained increased for $30 \mathrm{~min}$ after smoking (Fig. 5). Subjective fatigue at $30 \mathrm{~min}$ after smoking $(14.7 \pm 1.6)$ was higher $(P<0.05)$ than after exercise $(8.2 \pm 2.1)$ and in the control $(8.5 \pm 2.0)$.

\section{Discussion}

The major findings of this study are: 1) palmar CVC that decreased due to $2 \mathrm{hr}$ MT further decreased with smoking up to $20 \mathrm{~min}$ after the intervention, 2) the MT-induced reductions in the palmar CVC were reversed by light exercise and the vasodilator effects of exercise persisted for half an hour after the intervention. These findings suggest that smoking and physical exercise after a prolonged MT induce contrary effects in vasomotor responses in glabrous skin.

The $2 \mathrm{hr}$ mental arithmetic task increased blood pressure without changing HR (Table 1). These results are consistent with a previous study [24] that performed six successive trials of a 10 min mental arithmetic task. Nielsen et al. [14] showed that elevated blood pressure and reduced SkBF on the volar side of the thumb with a $1 \mathrm{hr}-\mathrm{MT}$ did not recover during a $30 \mathrm{~min}$ recovery period. Analogous to the report of Nielsen et al. [14], we observed long lasting skin 

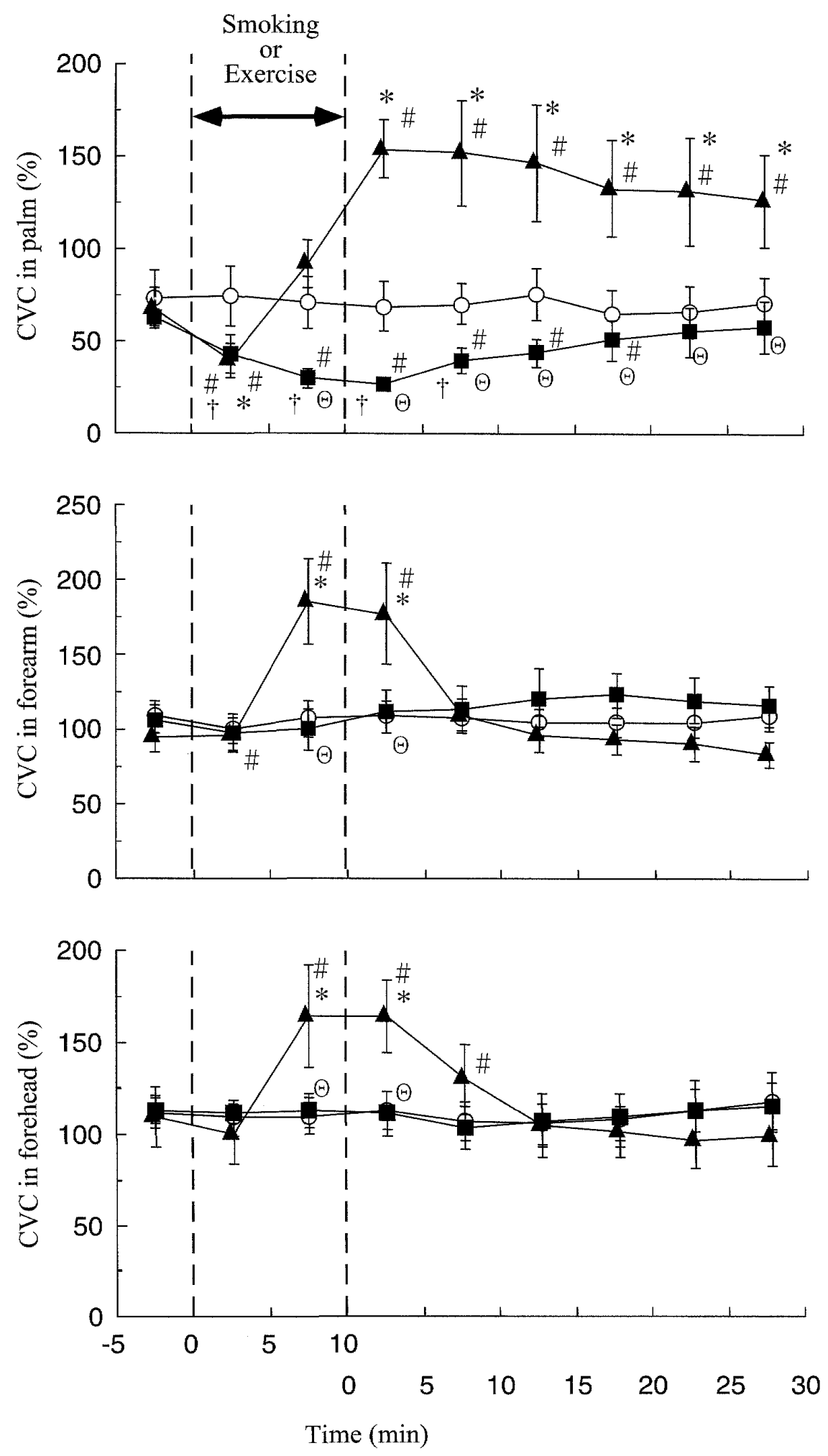

Fig. 2. Changes in cutaneous vascular conductance (CVC) in the palm, forearm and forehead in three interventions ( $\boldsymbol{\square}$ : smoking, $\boldsymbol{\Lambda}$ : exercise, $\mathrm{O}$ : time control) after a prolonged mental task. The CVC are expressed as a percentage from the baseline values before the mental task. \#: $P<0.05$ from the pre-intervention baseline, $\uparrow: P<0.05$ Smoking vs Control, *: $P<0.05$ Exercise vs Control, $\Theta: P<0.05$ Smoking vs Exercise. 

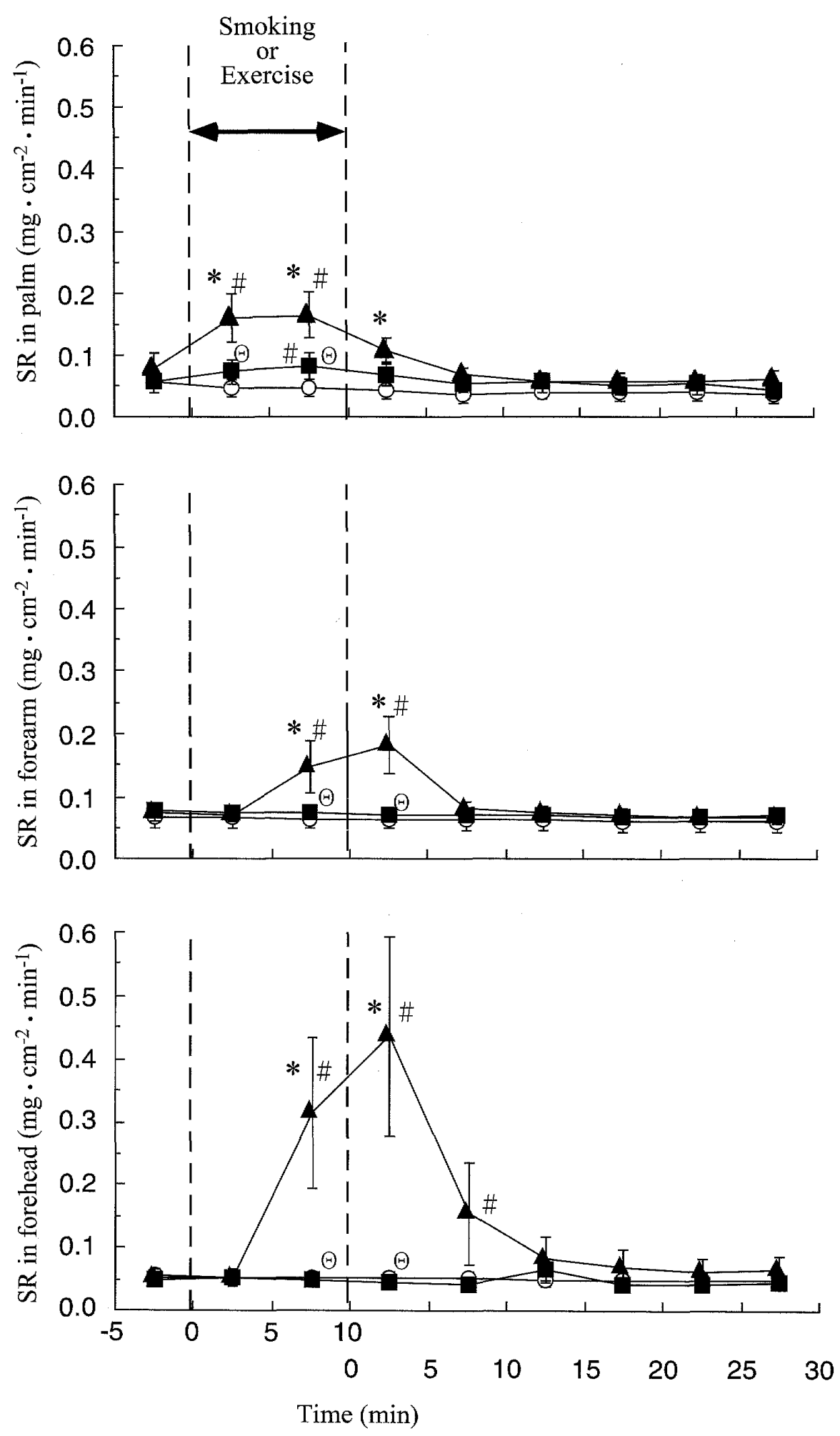

Fig. 3. Changes in sweating rate (SR) in the palm, forearm and forehead with the three interventions. ( $\mathbf{\square}$ : smoking, $\boldsymbol{\Delta}$ : exercise, $O$ : time control) after a prolonged mental task. \#: $P<0.05$ from the pre-intervention baseline, * $P<0.05$ Exercise vs Control, $\Theta: P<0.05$ Smoking vs Exercise. 

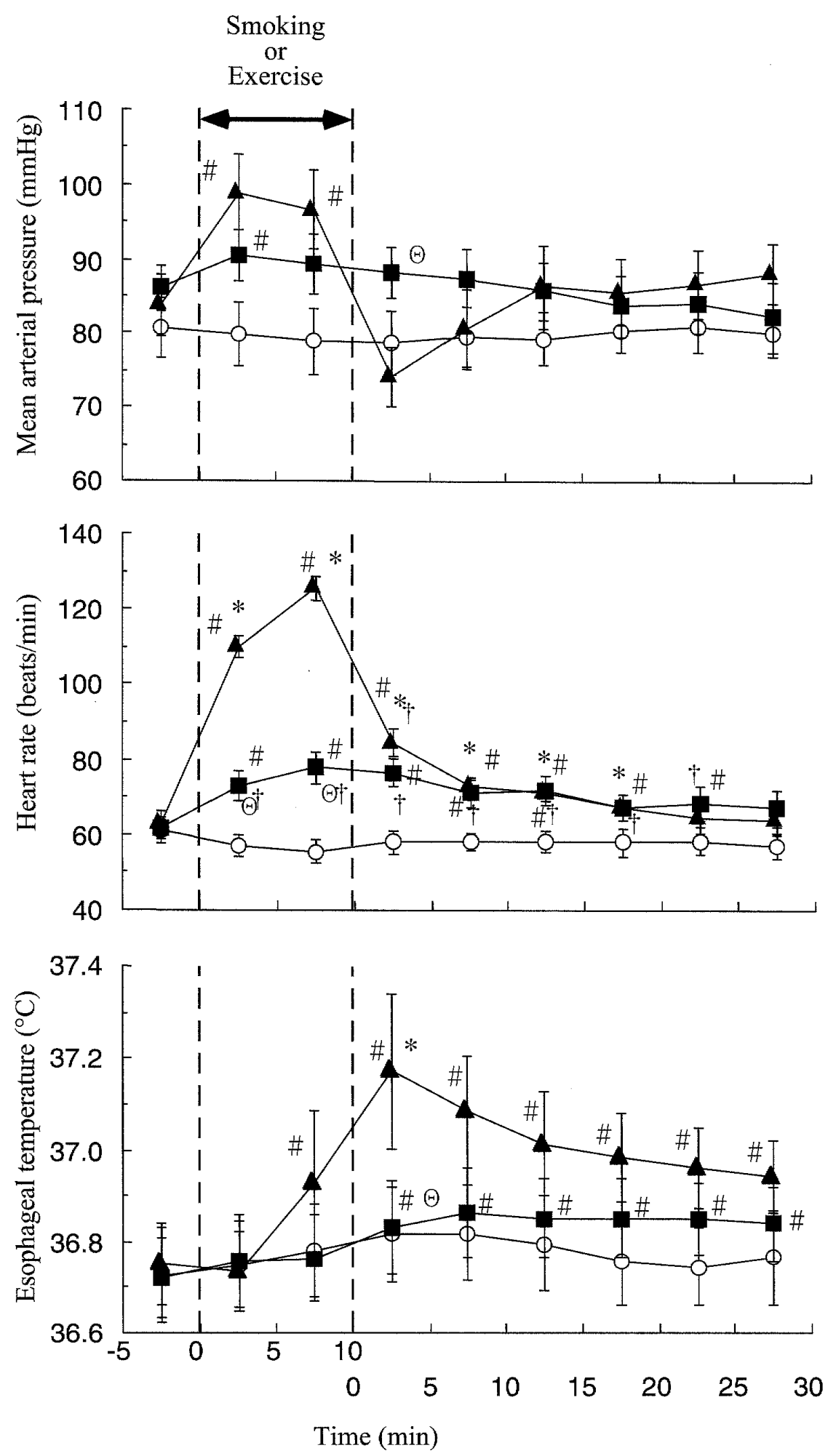

Fig. 4. Changes in mean arterial pressure, heart rate and esophageal temperature with the three-interventions ( $\mathbf{\square}$ : smoking, $\mathbf{\Delta}$ : exercise, $\bigcirc$ : time control) after a prolonged mental task. \#: $P<0.05$ from the pre-intervention baseline, $\dagger: P<0.05$ Smoking vs Control, *: $P<0.05$ Exercise vs Control, $\Theta: P<0.05$ Smoking vs Exercise. 


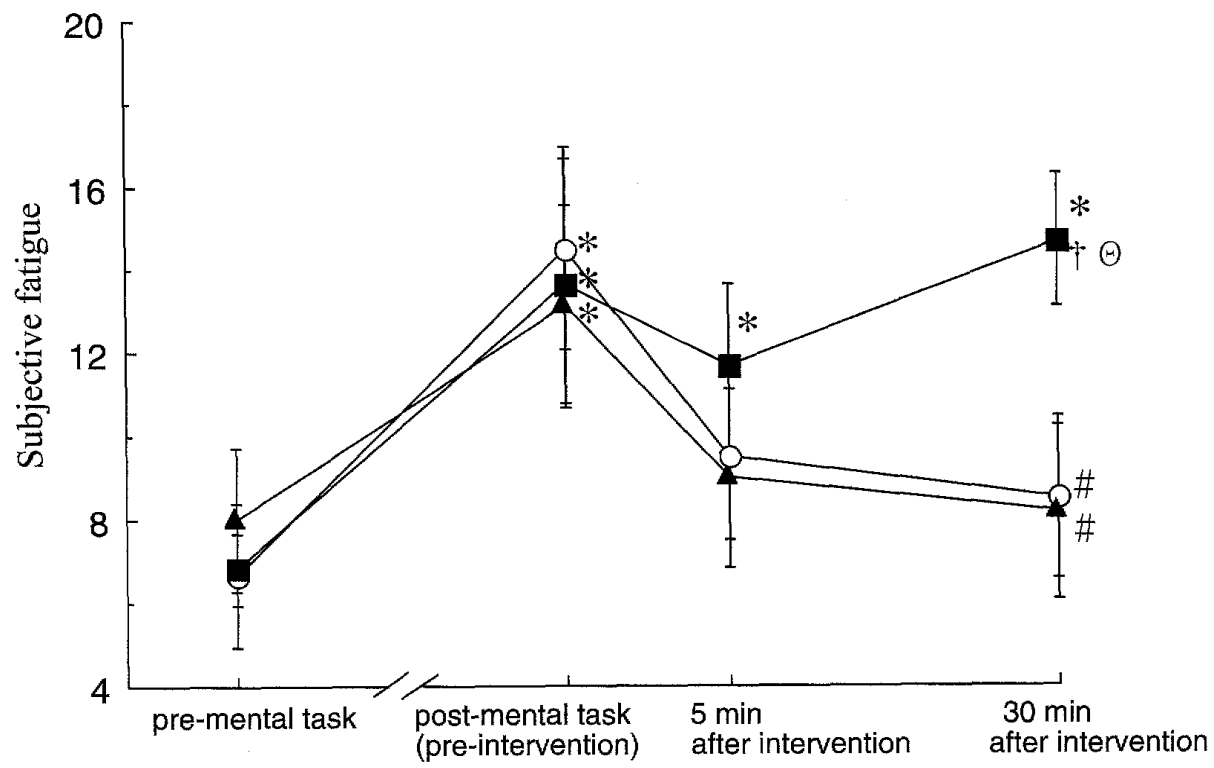

Fig. 5. Changes in subjective fatigue with a prolonged mental task followed by the three interventions ( $\boldsymbol{\square}$ : smoking, $\boldsymbol{\Lambda}$ : exercise, $O$ : time control). ${ }^{*}: P<0.05$ from premental task, \#: $P<0.05$ from the pre-intervention baseline, $\dagger: P<0.05$ Smoking vs Control, $\Theta: P<0.05$ Smoking vs Exercise.

vasoconstriction in the palm, but not in the forearm or forehead, after the prolonged MT in a thermally comfortable condition $\left(25^{\circ} \mathrm{C}\right)$. Regionally different vasomotor responses in the skin have been previously observed during short-term MT. Yano et al. [13] found that 2 min mental arithmetic reduced $\mathrm{CVC}$ in the palm and foot to a greater extent than in the calf and forearm under thermoneutral conditions $\left(28^{\circ} \mathrm{C}\right)$. Meanwhile, mental arithmetic or arousal stimuli increased sympathetic nerve activity in the supraorbital nerve followed by increases in SkBF and sweating activity in the forehead during normothermia and body heating [25]. The greater vasoconstrictor response in glabrous skin during physical and mental stress may be due to a marked constriction in arteriovenous anastomoses (AVAs) to sympathetic nerve activity [13, 19, 21]. The conflicting results in vascular responses during mental stress may also be due to the different thermal conditions. Previous reports $[26,27]$ showed that a number of stimuli containing mental stress led to skin vasoconstriction in glabrous sites in the hands and feet if the subjects were warm (skin temperature $>30^{\circ} \mathrm{C}$ ). If the subjects were cold (skin temperature $<25^{\circ} \mathrm{C}$ ), the same stimuli evoked vasodilation. Additionally, significant vasoconstrictor responses during mental stress were observed at foot skin sites at higher local temperatures $\left(34\right.$ and $\left.39^{\circ} \mathrm{C}\right)$, but not at a lower local temperature $\left(29^{\circ} \mathrm{C}\right)[12]$. Thus, it is surmised that the skin vasoconstrictor response to mental stress is increased in warmer conditions.

The findings that smoking induced tachycardia and pressor responses were consistent with previous reports [28-32]. In conjunction with elevating blood pressure, smoking induced skin vasoconstriction in the palm and forearm but not in forehead. Previous studies $[17,28,33]$ reported in regular smokers that smoking consistently reduced SkBF in the fingers, but there were 
also regional differences in the smoking-induced reduction in SkBF. Allison and Roth [28] showed by using impedance plethysmography that the reductions in blood flow during smoking were greater in the fingers and toes than in the calf. Goodfield et al. [17] observed a smokinginduced reduction in blood flow in the finger tips, but not in the dorsal finger, while forehead SkBF tended to increase during smoking [34].

In this study, the significant vasoconstrictor response in the palm persisted up to $20 \mathrm{~min}$ after smoking, whereas that in the forearm only occurred in the early phase of smoking. Thus, it is thought that the smoking-induced vasoconstriction in the skin consistently occurs in glabrous sites rather than in nonglabrous sites. The detailed mechanisms in skin vasoconstriction due to smoking are less clear, but can be inferred. The smoking-associated increments in HR and blood pressure are mediated through adrenergic mechanisms because no significant increments in these variables occurred with smoking during adrenergic blockade [31]. Since 10 min smoking quickly increases plasma noradrenaline, the smoking-associated changes in cardiovascular variables are due to local release of the sympathetic neurotransmitter noradrenaline from adrenergic nerve terminals [31]. Furthermore, it has been shown that the reduction in SkBF induced by smoking is due to enhanced vasopressin secretion [35]. The regionality in the skin vascular responses during smoking may be a result of different activation in sympathetic nerves and/or different reactivity of adrenergic and/or vasopressin receptors in each region. The presence of $\alpha$ and $\beta$ adrenergic receptors has been reported in forearm skin vasculature [36, 37]. The distribution of adrenergic receptors in human skin may also differ in each region. Alternatively, inhibition of prostacyclin formation by smoking may be involved in the vascular responses [28, 38]. Since the sensitization in the vasoconstricting effect of smoking is partly mediated by the inhibition of endothelial prostacyclin synthesis [17], it is speculated that the sensitization and/or vascular prostacyclin formation are different in each region. Moreover, cigarette smoke contains nicotine, tar products, reactive free radicals, carbon monoxide, and numerous other chemicals [39-41]. Therefore, it is thought that multiple chemicals in cigarette smoke act to constrict skin vessels and those actions may also cause the regionality in the vascular responses.

Physical exercise, a sympathetic activator, also increased HR and blood pressure. It is thought that an increase in the core temperature by cycle exercise induces vasodilation and thermal sweating in nonglabrous skin sites (i.e. forearm and forehead). Mental excitation as a nonthermal influence on thermoregulatory function increased SR in glabrous skin, as well as in nonglabrous skin during cycle exercise [42]. In the palm, exercise transiently decreased in the early phase and subsequently increased CVC above the baseline levels before MT, and the skin vasodilation persisted until $30 \mathrm{~min}$ after exercise. Since exercise-induced elevations of CVC in the forearm and forehead were not lasting $(<10 \mathrm{~min})$, the thermal vasodilator effect on AVAs may be different from that on the nutritional microvasculature.

Smoking increased palmar sweating, suggesting that the intervention induced mental excitation. Regardless of the suggested mental excitation, smoking did not reduce subjective fatigue for $30 \mathrm{~min}$ at least, although light exercise and control rest without smoking immediately reduced these feelings after MT. Thus, the effectiveness of smoking in alleviating feelings of tiredness is questionable. Furthermore, since smoking is well known as a major risk factor in the devel- 
opment and progression of cardiovascular disease [43], it is thought that it is not an appropriate intervention for short work place breaks.

Cutaneous circulation is the main effector organ for human thermoregulation. Additionally, the vascular dysfunction is an important issue for pathophysiological research, because pathology-induced vascular dysfunction in the cutaneous circulation may mirror generalized systemic vascular dysfunction [15]. Nielsen et al. [14] suggested that a slow vascular recovery after prolonged MT in healthy subjects might be a risk for developing chronic stress-related disorders later in life. Thus the evident vasoconstriction in glabrous skin by smoking after MT may be a risk for cardiovascular disease. Further study is necessary for clinical relevance.

In conclusion, the present results suggest that smoking causes additional vasoconstriction in glabrous skin after prolonged MT, while exercise-induced vasodilation counteracts the vasoconstrictor influence of MT. Contrary to exercise or rest without smoking, acute smoking did not reduce the subjective fatigue caused by MT.

\section{Acknowledgement}

We thank all of the subjects for their time, effort, and willingness to participate in the study.

\section{References}

1. Hayashi N, Someya N, Yamaoka Endo M, Miura A\&Fukuba Y (2006): Vasoconstriction and blood flow responses in visceral arteries to mental task in humans. Exp Physiol 91: 215-220

2. Halliwill JR, Lawler LA, Eickhoff TJ, Dietz NM, Nauss LA \& Joyner MJ (1997): Forearm sympathetic withdrawal and vasodilatation during mental stress in humans. J Physiol 504: 211-220

3. Wasmund WL, Westerholm EC, Watenpaugh DE, Wasmund SL \& Smith ML (2002): Interactive effects of mental and physical stress on cardiovascular contrrol. J Appl Physiol 92: 1828-1834

4. Bairey CN, Krantz DS \& Rozanski A (1990): Mental stress as an acute trigger of ischemic left ventricular dysfunction and blood pressure elevation in coronary artery disease. Am J Cardiol 66: 28G-31G

5. Ghiadoni L, Donald AE, Cropley M et al (2000): Mental stress induces transient endothelial dysfunction in humans. Circulation 102: 2473-2478

6. Morimoto K, Morikawa M, Kimura H, Ishii N, Takamata A, Hara Y, Uji M\& Yoshida K (2008): Mental stress induces sustained elevation of blood pressure and lipid peroxidation in postmenopausal women. Life Sci 82: 99-107

7. Esler M, Eikelis N, Schlaich M et al (2008): Chronic mental stress is a cause of essential hypertension: presence of biologicl markers of stress. Clin Exp Pharmacol Physiol 35: 498-502

8. Carter JR \& Ray CA (2009): Sympathetic neural responses to mental stress: responders, nonresponders and sex differences. Am J Physiol Heart Circ Physiol 296: H847-H853

9. Myrtek M\& Spital S (1986): Psychophysiological response patterns to single, double, and triple stressors. Psychophysiol 23: 663-671

10. Rousselle JG, Blascovich J \& Kelsey RM (1995): Cardiorespiratory response under combined psychological and exercise stress. Int J Psychophysiol 20: 49-58 
11. Seliger SL, Katzel LI, Fink JC, Weir MR \& Waldstein SR (2008): Renal function and cardiovascular response to mental stress. Am J Nephrol 28: 304-310

12. Yamazaki F, Kinoshita K\& Sone R (2009): Interactive effects between isometric exercise and mental stress on the vascular responses in glabrous and nonglabrous skin. J Physiol Sci 59: 137-142

13. Yano H, Sone R\& Yamazaki F (2009): Vascular responses in glabrous and nonglabrous skin during acute mental stress in physically trained humans. J UOEH 31: 325-337

14. Nielsen KB, Sand T, Stovner LJ, Leistad RB \& Westgaard RH (2007): Autonomic and muscular responses and recovery to one-hour laboratory mental stress in healthy subjects. BMC Musculoskeletal Disorders 8: 81

15. Holowatz LA, Thompson-Torgerson CS \& Kenney WL (2008): The human cutaneous circulation as a model of generalized microvascular function. J Appl Physiol 105: 370-372

16. Allison RD \& Roth GM (1969): Central and peripheral vascular effects during cigarette smoking. Arch Environ Health 19: 189-198

17. Goodfield MJ, Hume A\&Rowell NR (1990): The acute effects of cigarette smoking on cutaneous blood flow in smoking and non-smoking subjects with and without Raynaud's phenomenon. Br J Rheumatol 29: 89-91

18. Winniford, MD, Wheelan KR, Kremers MS, Ugolini V, van den Berg E, Jr, Niggemann EH, Jansen DE \& Hillis LD (1986): Smoking-induced coronary vasoconstriction in patients with atherosclerotic coronary artery disease: evidence for adrenergically mediated alterations in coronary artery ton. Circulation 73: 662-627

19. Saad AR, Stephens DP, Bennett LAT, Charkoudian N, Kosiba W \& Johnson JM (2001): Influence of isometric exercise on blood flow and sweating in glabrous and nonglabrouss human skin. J Appl Physiol 91: 2487-2492

20. Yamazaki F (2002): Vasomotor responses in glabrous and nonglabrous skin during sinusoidal exercise. Med Sci Sports Exerc 34: 767-772

21. Yamazaki F \& Sone R (2006): Different vascular responses in glabrous and nonglabrous skin with increasing core temperature during exercise. Eur J Appl Physiol 97: 582-590

22. Yanagimoto S, Kuwahara T, Zhang Y, Koga S, Inoue Y \& Kondo N (2003): Intensity-dependent thermoregulatory responses at the onset of dynamic exercise in mildly heated humans. Am J Physiol 285: R200-R207

23. McNair DM, Lorr M\&Droppleman LF (1981): Manual for the profile of mood states. Educational and Industrial Testing Service, San Diego, CA pp 3-29

24. Yamada S \& Miyake S (2007): Effects of long term mental arithmetic on physiological parameters, subjective indices and task performances. J UOEH 29:27-38

25. Nordin M (1990): Sympathetic discharges in the human supraorbital nerve and their relation to sudoand vasomotor responses. J Physiol 423: 241-255

26. Elam M\&Wallin BG (1987): Skin blood flow responses to mental stress in man depend on body temperature. Acta Physiol Scand 129: 429-431

27. Wallin BG (1990): Neural control of human skin blood flow. J Auton Nerv Syst 30: S185-S190

28. Allison RD\& Roth GM (1969): Central and peripheral vascular effects during cigarette smoking. Arch Environ Health 19:189-198 
29. Barutcu I, Esen AM, Degirmenci B, Acar M, Kaya D, Turkmen M, Melek M, Onrat E, Esen OB \& Kirma C (2004): Acute cigarette smoking-induced hemodynamic alterations in the common carotid artery - a transcranial Doppler study -. Circ J 68 : 1127-1131

30. Brunel P, Girerd X, Laurent S, Pannier B\& Safar M (1992): Acute changes in forearm haemodynamics produced by cigarette smoking in healthy normotensive non-smokers are not influenced by propranolol or pindolol. Eur J Clin Pharmacol 42: 143-146

31. Cryer PE, Haymond MW, Santiago JV \& Shah SD (1976): Norepinephrine and epinephrine release and adrenergic mediation of smoking-associated hemodynamic and metabolic events. N Engl J Med 295: $573-577$

32. Terborg C, Bramer S, Weiller C\&Röther J (2002): Short-term effect of cigarette smoking on $\mathrm{CO}_{2}-$ induced vasomotor reactivity in man: a study with near-infrared spectroscopy and tanscranial Doppler sonography. J Neurol Sci 205: 15-20

33. Richardson D (1987): Effects of tobacco smoke inhalation on capillary blood flow in human skin. Arch Environ Health 42: 19-25

34. Meekin TN, Wilson RF, Scott DA, Ide M\& Palmer RM (2000): Laser Doppler flowmeter measurement of relative gingival and forehead skin blood flow in light and heavy smokers during and after smoking. J Clin Periodontol 27: 236-242

35. Waeber B, Schaller MD, Nussberger J, Bussien JP, Hofbauer KG\& Brunner HR (1984): Skin blood flow reduction induced by cigarette smoking: role of vasopressin. Am J Physiol Heart Circ Physiol 247: H895-H901

36. Crandall CG, Etzel RA\& Johnson JM (1997): Evidence of functional $\beta$-adrenoceptors in the cutaneous vasculature. Am J Physiol Heart Circ Physiol 273: H1038-H1043

37. Stephens DP, Aoki K, Kosiba WA \& Johnson JM (2001): Nonnoradrenergic mechanism of reflex cutaneous vasoconstriction in men. Am J Physiol Heart Circ Physiol 280: H1496-H1504

38. Nadler J, Velasco JS \& Horton R (1983): Cigarette smoking inhibits prostacyclin formation. Lancet 1: 1248-1250

39. Benowitz NL (1988): Drug therapy. Pharmacologic aspects of cigarette smoking and nicotine addition. N Engl J Med 17: 1318-1330

40. Murohara T, Kugiyama K, Ohgushi M, Sugiyama S \& Yasue H (1994): Cigarette smoke extract contracts isolated porcine coronary arteries by superoxide anion-mediated degradation of EDRF. Am J Physiol Heart Circ Physiol 266: H874-H880

41. Tsuchiya M, Thompson DF, Suzuki YJ, Cross CE \& Packer L (1992): Superoxide formed from cigarette smoke impairs polymorphonuclear leukocyte active oxygen generation activity. Arch Biochem Biophys 299: 30-37

42. Yamazaki F, Sone R\& Ikegami H (1994): Responses of sweating and body temperature to sinusoidal exercise. J Appl Physiol 76: 2541-2545

43. Shinton R \& Beevers G (1989): Meta-analysis of relation between cigarette smoking and stroke. BMJ 298: 789-794 
習慣的喫煙者における長時間メンタルストレス後の喫煙は無毛部の皮膚血管をより 一層収縮させる

上原 紘平 1 , 兽根 涼子 1 , 山崎 文夫 ${ }^{2}$

${ }^{1}$ 山口大学 教育学部 スポーツ健康科学教室

2産業医科大学 産業保健学部 人間情報科学

要

旨：喫煙と運動はメンタルストレス後の末梢血管運動調節に異なる影響をもたらすとい う仮説を検証するために，6名の喫煙者を対象として喫煙と運動に対する皮膚血管反 応を含む生理的反応を検討した，快適な温度条件下 $\left(25^{\circ} \mathrm{C}\right)$ において喫煙者は 2 時間の 暗算作業 $(\mathrm{MT})$ 後に10分間の猰煙あるいは自転車運動を行うか, あるいはそのいずれ も行わないで安静を保った(time control実験)。皮膚血流量 (レーザードップラー流量 法)を無毛部(手掌) と有毛部(前腕, 前額)でモニターした，皮膚血管コンダタタンス (CVC) を平均血圧 (MAP)に対する血流量の比率から評価した.MAPは長時間のMTに よって77.7 $2.7 \mathrm{mmHg} ら 86.0 \pm 3.0 \mathrm{mmHg}$ 上昇した. CVCはMTによって手掌部で

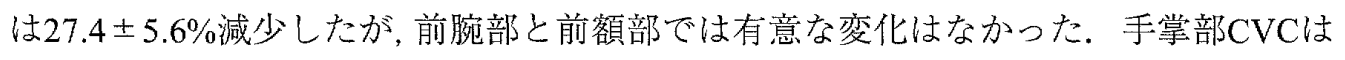
MT後の契煙によってさらに減少し, その契煙によるCVCの減少は喫煙後20分間継続 した。一方, 契煙中の前腕部と前額部のCVC減少は小さくかつ一過性であった。いず れの部位においてもCVCはMT後の連動によって増加し, 運動による手掌部CVCの増 加は運動後30分間継続した. Time control 実験においていずれのパラメーターもMT後 の回復期間中に有意な変化はみられなかった。これらのことから契煙は長時間MT後 に無毛部皮膚血管収縮をさらに強めるが, 運動による血管拡張効果はMTによる血管 収縮作用を和らげることが示唆された。長期間のメンタルストレスと喫煙行動は慢 性ストレスに関連した血管系疾患を共働作用的に発症させ, そのストレス関連疾患は 習慣的に適度な運動を行うことによって低減する可能性が示唆された。

キーワード： 皮膚血流量, メンタルストレス, 運動, 契煙, 発汗.

J UOEH（産業医大誌）32（4）：303-316（2010） 